\title{
New records of a poorly studied mayfly species, Eurylophella karelica Tiensuu, 1935 (Ephemeroptera, Ephemerellidae), in the Baltic Ecoregion
}

\author{
Dāvis Ozoliņš, ${ }^{1}$ Jolanta Jēkabsone, ${ }^{1}$ Agnija Skuja, ${ }^{1}$ Henn Timm ${ }^{2}$ \\ 1 Institute of Biology, University of Latvia, 3 Miera Street, LV-2169, Salaspils, Latvia. 2 Estonian University of Life Sciences, 61101 Rannu, \\ Tartumaa, Estonia. \\ Corresponding author: Dāvis Ozoliṇ̌s, davis.ozolins@lu.lv
}

\begin{abstract}
Eurylophella karelica is a rare and poorly investigated species of European Ephemeroptera from the family Ephemerellidae. From the 1930s to 1970s, E. karelica has not been reported from historical localities in Karelia, Lithuania and Poland. New localities from Hungary, Slovenia and Lithuania are discovered over the last 2 decades. This article reports first findings of E. karelica in Latvia and Estonia and explains sporadic distribution of this species.
\end{abstract}

\section{Key words}

Ephemerellidae; new localities; Latvia; Estonia.

Academic editor: Rodolfo Silva | Received 7 June 2016 | Accepted 13 June 2017 | Published 18 August 2017

Citation: Ozoliňš D, Jēkabsone J, Skuja A, Timm H (2017) New records of a poorly studied mayfly species, Eurylophella karelica (Ephemeroptera, Ephemerellidae) Tiensuu, 1935, in the Baltic Ecoregion. Check List 13 (4): 349-353. https://doi.org/10.15560/13.4.349

\section{Introduction}

In Europe, the genus Eurylophella Tiensuu, 1935 is represented by three species (Martynov et al. 2015). Eurylophella karelica was the first species described in this genus (Tiensuu 1935). Eurylophella iberica is endemic to Iberian Peninsula (Keffermüller and Da Terra 1978) and E. korneyevi was recently described from Caucasus region of Georgia (Martynov et al. 2015). Overall, genus Eurylophella has a Holarctic distribution with 19 valid species (Burian 2002, Bauernfeind and Soldán 2012, Martynov et al. 2015).

Eurylophella karelica was found in Karelia, formerly Finland (Tiensuu 1935), Lithuania (Kazlauskas 1959, Ruginis 2006, Kovács et al. 2008, 2011), Poland (Keffermüller 1960, Sowa 1961), Hungary and Slovenia (Kovács and Ambrus 1999). However, no recent records from historical localities in Karelia (Tiensuu 1935) and Poland (Jazdzewska 1995) are known. As it is extirpated from several localities, E. karelica was considered as one of the most threatened European mayflies (Kovács and Ambrus 1999).

Little is known regarding biology and ecology of $E$. karelica (Bauernfeind and Soldán 2012). Larvae were found in slow-flowing stretches of rivers and brooks (Kazlauskas 1959, Sowa 1961), as well as in lakes (Keffermüller 1960). Stones, gravel, clay (Tiensuu 1935), submerged macrophytes, roots of riparian vegetation, organic debris (Kovács and Ambrus 1999) and muddy sediment (Sowa 1961) were observed as their preferred habitats. Details of its life cycle are not thoroughly reported. Larvae have been found in late summer, autumn and spring but not in early and mid-summer (Tiensuu 


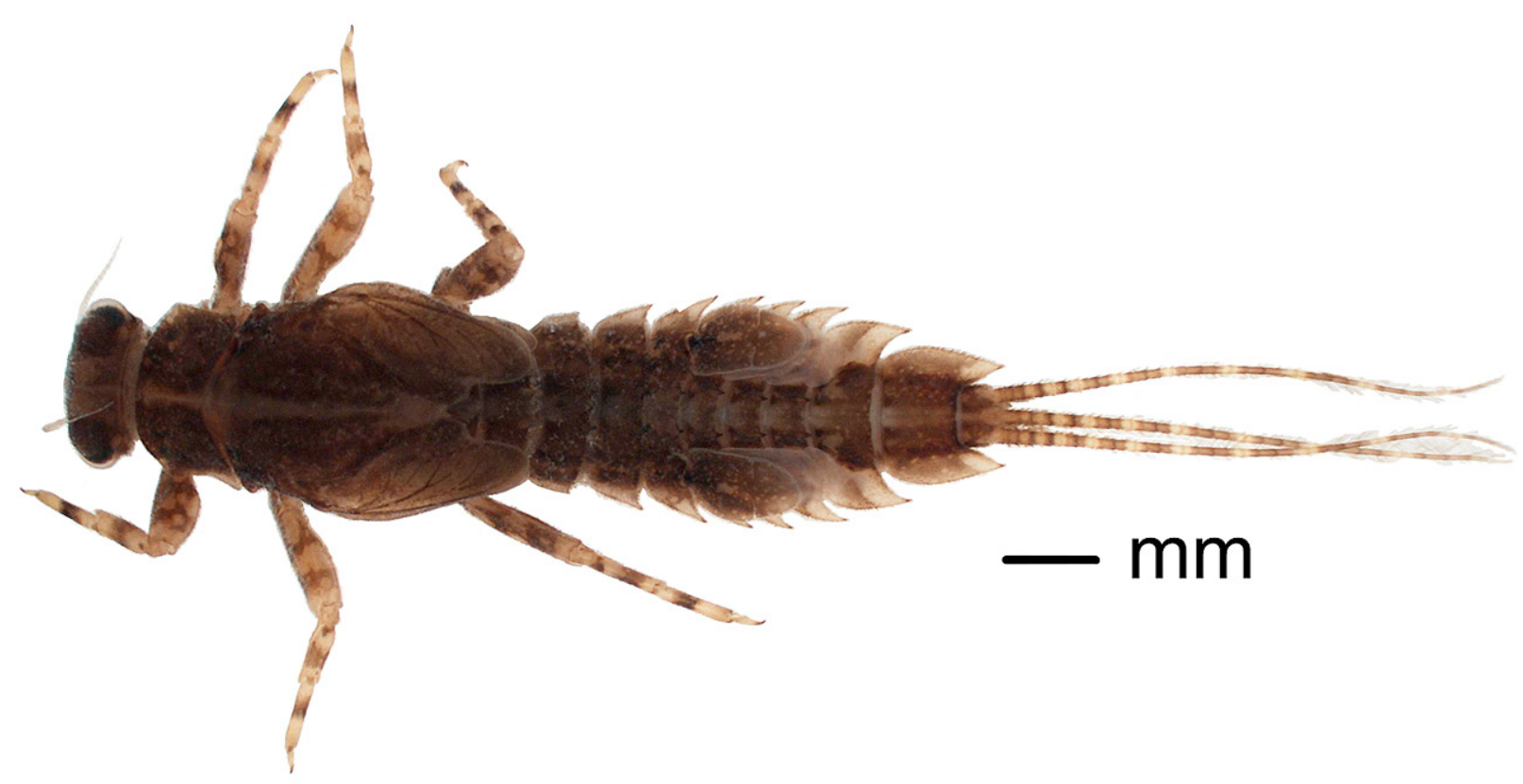

Figure 1. Nymph of Eurylophella karelica from Estonia (collected in the Narva River, downstream, 30.09.2010). Scale bar $=1 \mathrm{~mm}$.

1935, Kazlauskas 1959, Kovács et al. 2008, Keffermüller 1960, Sowa 1961, Kovács and Ambrus 1999). Imagines were collected in May, and thus, the life cycle is probably univoltine, overwintering as the larval stage (Uw) (Bauernfeind and Soldán 2012).

This article reports first records of E. karelica (Fig. 1) in Latvia and Estonia, additionally, clarifying disjunctive distribution of the species.

\section{Methods}

Our study comprises 1) the database of Institute of Biology, University of Latvia, 2) the data of surface water monitoring programme in Latvia, from 2007 to 2013 performed by Latvian Environment, Geology and Meteorology Centre, and 3) the data of E. karelica localities in Estonia, provided by Estonian University of Life Sciences.

The localities of species distribution elsewhere in Europe were obtained from publications (Tiensuu 1935, Kazlauskas 1959, Keffermüller 1960, Sowa 1961, Kovács et al. 2008, 2011, Kovács and Ambrus 1999).

The larvae of E. karelica in Latvia and Estonia were found in autumn (September-November) and spring (April-May) in lowland streams and rivers. In Latvia, the larvae were found in 9 localities of 7 watercourses, while in Estonia, in 10 watercourses, and exceptionally, in the littoral zone of a Lake Tündre (Table 1).

\section{Results}

Material examined. Table 1.

The main characteristic differentiating larvae in genus Eurylophella are the shape of the paired tubercles on abdominal terga (Allen and Edmunds 1963). In E. karelica, tubercles are long, blunt or moderately sharp on segments $1-3$, long and sharp on segments 4-7 and short, barely discernible or absent on segments 8-10 (Fig. 1). Nymphs of E. karelica were identified using published keys (Allen and Edmunds 1963, Bauernfeind and Soldán 2012, Martynov et al. 2015). Species identification was approved by Dr Henn Timm from Estonian University of Life Sciences.

\section{Discussion}

Nymphs of E. karelica were reported from waterbodies situated on plains (Tiensuu 1935, Kazlauskas 1959, Keffermüller 1960, Sowa 1961, Kovács and Ambrus 1999, Kovács et al. 2008). Lithuania, Latvia and Estonia are located in the Baltic Province (Ecoregion No. 15), which also is a lowland area (Illies 1978). Thus, we suggest that E. karelica is a lowland species, as it is shown on the distribution map (Fig. 2). The new localities are the first records of E. karelica in Estonia and Latvia. Within the Baltic region, they were previously reported only in Lithuania. The record from the littoral zone of Lake Tündre in Estonia was the second case from the lentic habitat since Keffermüller (1960) found E. karelica in Lake Góreckie, a post-glacial, mesotrophic lake in Poland.

The data corroborated earlier reports, which regard $E$. karelica as a relict of the last Ice Age (Keffermüller 1960, Kovács and Ambrus 1999). The absence of nymphs during the summer sampling could be caused either by summer egg diapause or by larvae being too small to be detected by routine sampling methods (Bohle 1972, Brittain 1982). A summer egg diapause have been discussed in North American species of the genus Eurylophella (Hamilton and Tarter 1977). However, detailed life cycle studies of E. karelica are required to justify these statements. 
The distribution of E. karelica was considered sporadic with small refugial areas (Kovács and Ambrus 1999). The current findings suggest that this species is more widespread than it was previously predicted. The reasons for this could be inappropriate sampling season (summer) to detect the larvae or absence of the research. Nevertheless, E. karelica mostly occurred in small numbers at the reported sampling sites (Tiensuu 1935, Kazlauskas 1959, Keffermüller 1960, Kovács and Ambrus 1999) suggesting relatively low abundances within its habitats. According to Kovács and Ambrus
1999, May is the proper sampling season for adults.

We assume that E. karelica inhabit a wider range of European lowland watercourses than expected before. However, appropriate sampling season (autumn to spring) should be considered first to improve the distribution pattern of this species.

\section{Acknowledgements}

We thank Natalja Grudule and Marina Čičendajeva from Latvian Environment, Geology and Meteorology Centre

Table 1. The places of finding of Eurylophella karelica in Latvia and Estonia during 2007-2013.

\begin{tabular}{llll}
\hline No. & Latitude $(\mathrm{N})$ & Longitude $(\mathrm{E})$ & Details \\
\hline 1 & $56^{\circ} 05.0484^{\prime}$ & $021^{\circ} 09.9396^{\prime}$ & Latvia, Sventāja Stream, at Latvian-Lithuanian border, 22.10.2008, 1 nymph leg./det. N. Grudule, voucher \\
& & specimen deposited in "Benthic macroinvertebrate sample collections" of "Surface water monitoring pro- \\
& & gramme in Latvia" in Latvian Environment, Geology and Meteorology Centre; the same locality, 20.10.2013, \\
& & 3 nymphs, leg./det. D. Ozoliňš, voucher specimens deposited in "Hydrobiological collections" of Institute of \\
& & Biology, University of Latvia, project No. LLIV-230.
\end{tabular}

$2 \quad 56^{\circ} 21.8712^{\prime} \quad 021^{\circ} 13.1064^{\prime \prime}$

Latvia, Bărta River, $0.2 \mathrm{~km}$ upstream of Dūkupji, 08.05.2007, 6 nymphs leg./det. N. Grudule; the same locality 06.05.2009, 4 nymphs, leg./det. N. Grudule, voucher specimens deposited in “Benthic macroinvertebrate sample collections of "Surface water monitoring programme in Latvia" in Latvian Environment, Geology and Meteorology Centre.

Latvia, Tebra Stream, mouth, 14.10.2008, 1 nymph, leg./det. N. Grudule, voucher specimen deposited in "Benthic macroinvertebrate sample collections" of "Surface water monitoring programme in Latvia" in Latvian Environment, Geology and Meteorology Centre.

Latvia, Abava River, upstream of Kandava, 20.05.2009, 1 nymph, leg./det. N. Grudule, voucher specimen deposited in "Benthic macroinvertebrate sample collections" of "Surface water monitoring programme in Latvia" in Latvian Environment, Geology and Meteorology Centre.

Latvia, Abava River, upstream of Pūre, 15.10.2008, 3 nymphs, leg./det. N. Grudule, voucher specimens deposited in "Benthic macroinvertebrate sample collections" of "Surface water monitoring programme in Latvia" in Latvian Environment, Geology and Meteorology Centre.

Latvia, Mēmele River, mouth, 01.11.2013, 2 nymphs, leg. A. Skuja, det. D. Ozoliņš, voucher specimens deposited in "Hydrobiological collections" of Institute of Biology, University of Latvia, project No. LLIV-230.

Latvia, Mēmele River, at Latvian-Lithuanian border, 16.05.2011, 2 nymphs leg./det. N. Grudule, voucher specimens deposited in "Benthic macroinvertebrate sample collections" of "Surface water monitoring programme in Latvia" in Latvian Environment, Geology and Meteorology Centre; the same locality, 16.11.2013, 1 nymph, leg. A. Skuja, det. D. Ozoliňš, voucher specimen deposited in "Hydrobiological collections" of Institute of Biology, University of Latvia, project No. LLIV-230.

Latvia, Viesīte Stream, mouth, 22.11.2013, 2 nymphs, leg. A. Skuja, det. D. Ozoliňš, voucher specimens deposited in "Hydrobiological collections" of Institute of Biology, University of Latvia, project No. LLIV-230.

Latvia, Dienvidsusēja River, downstream of Nereta, 22.11.2013, 1 nymph, leg. A. Skuja, det. D. Ozoliňš, voucher specimen deposited in "Hydrobiological collections" of Institute of Biology, University of Latvia, project No. LLIV-230.

Estonia, Jägala Stream, Voose, 20.09.2010, 9 nymphs, leg. H. Timm, det. K. Käiro,voucher specimens deposited in "Hydrobiological collections" (EMHC) in Centre for Limnology, Estonian University of Life Sciences.

024 59.7000' Estonia, Halliste Stream, Riisa, 14.09.2010, 5 nymphs, leg./det. K. Käiro, voucher specimens deposited in "Hydrobiological collections" (EMHC) in Centre for Limnology, Estonian University of Life Sciences.

027 47.8300' Estonia, Narva River, downstream, 30.09.2010, 3 nymphs, leg. H. Timm, det. K. Käiro, voucher specimens deposited in "Hydrobiological collections" (EMHC) in Centre for Limnology, Estonian University of Life Sciences.

025⒓0900' Estonia, Lemmjogi Stream, Oksa, 28.04.2008, 2 nymphs, leg. H. Timm, det. K. Kairo, voucher specimens deposited in "Hydrobiological collections" (EMHC) in Centre for Limnology, Estonian University of Life Sciences.

02706.9000' Estonia, Rannapungerja Stream, downstream, 30.09.2010, 2 nymphs, leg./det. K. Käiro, voucher specimens deposited in "Hydrobiological collections" (EMHC) in Centre for Limnology, Estonian University of Life Sciences.

024ㄴ⒈1090’ Estonia, Reiu Stream, Metsaääre, 15.05.2012, 2 nymphs, leg./det. H. Timm, voucher specimens deposited in "Hydrobiological collections" (EMHC) in Centre for Limnology, Estonian University of Life Sciences. Estonia, Raudna Stream, Meiekose, 28.04.2008, 1 nymph, leg. H. Timm, det. K. Käiro, voucher specimen deposited in "Hydrobiological collections" (EMHC) in Centre for Limnology, Estonian University of Life Sciences. Estonia, Vasalemma Stream, at the bridge, 19.05.2010, 1 nymph, leg. H. Timm, det. K. Käiro, voucher specimen deposited in "Hydrobiological collections" (EMHC) in Centre for Limnology, Estonian University of Life Sciences.

Estonia, Väike Emajõgi Stream, 1 km downstream of Sangaste dam, 13.09.2010, 1 nymph, leg./det. H. Timm, voucher specimen deposited in "Hydrobiological collections" (EMHC) in Centre for Limnology, Estonian University of Life Sciences. Estonia, Rannapungerja Stream, Lemmaku 26.09.2011, 1 nymph, leg./det. U. Kruus, voucher specimen deposited in "Hydrobiological collections" (EMHC) in Centre for Limnology, Estonian University of Life Sciences. 


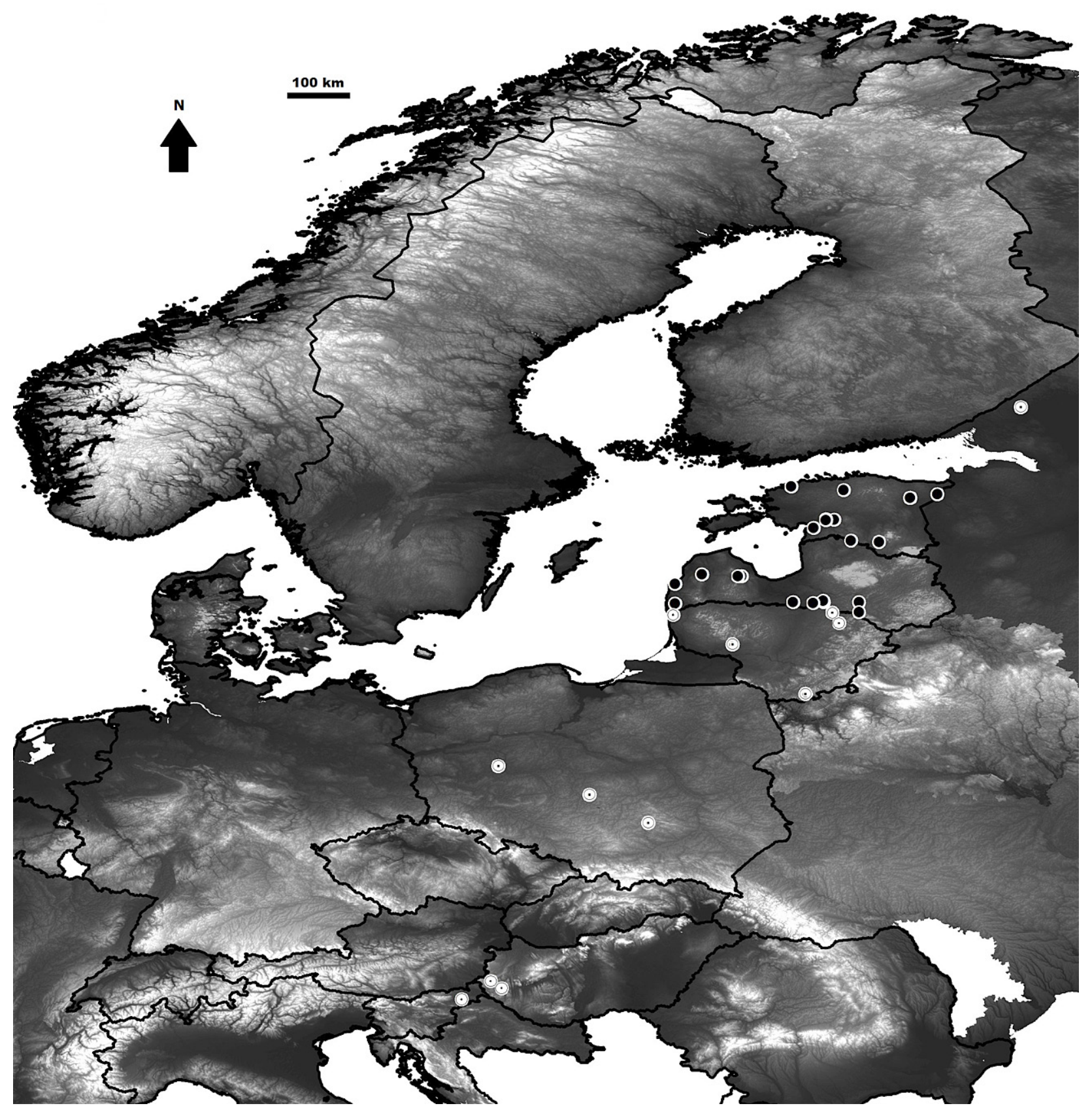

Figure 2. Distribution map of Eurylophella karelica. White dots: published localities from formerly Finland (Tiensuu 1935), Lithuania (Kazlauskas 1959, Kovács et al. 2008, Kovács et al. 2011), Poland (Keffermüller 1960, Sowa 1961), Hungary and Slovenia (Kovács and Ambrus 1999), black dots: new records from Latvia and Estonia (2007-2013).

for providing the data from surface water monitoring programme in Latvia. Authors also want to thank Ugis Kagainis for valuable comments on historical literature of Latvian arthropod collections.

\section{Authors' Contributions}

DO, AS and HT collected the data. DO and HT wrote the text. JJ made the map.

\section{References}

Allen RK, Edmunds GF (1963) A revision of the genus Ephemerella (Ephmereoptera: Ephemerellidae) VII. The subgenus Eurylophella. Canadian Entomologist 95 (6): 597-623.
Bauernfeind E, Soldán T (2012) The mayflies of Europe (Ephemeroptera). Apollo Books, Ollerup, Denmark, 781 pp.

Bohle HW (1972) Die Temperaturabhängigkeit der Embryogenese und der embryonalen Diapause von Ephemerella ignita (Poda) (Insecta, Ephemeroptera). Oecologia 10: 253-268. https://doi.org/10.1007/ BF00368967

Brittain JE (1982) Biology of mayflies. Annual Review of Entomology 27: 119-197. https://doi.org/10.1146/annurev.en.27.010182.001003 Burian SK (2002) Taxonomy of Eurylophella coxalis (McDunnough) with notes on larval habitat and behaviour (Ephemeroptera: Ephemerellidae). Journal of the North American Benthological Society 21 (4): 602-615. https://doi.org/10.2307/1468433

Hamilton DA, Tarter DC (1977) Life history and ecology of Ephemerella funeralis McDunnough (Ephemeroptera: Ephemerellidae) in a small West Virginia stream. American Midland Naturalist 98 (2): 458-462. https://doi.org/10.2307/2424993

Illies J (1978) Limnofauna Europaea. Checklist of the Animals Inhab- 
iting European Inland Waters with Accounts of their Distribution and Ecology (Except Protozoa). Gustav Fisher Verlag, Stuttgart, $532 \mathrm{pp}$.

Jazdzewska T (1995) Comparison of the ephemeropteran fauna of the Swietokrzyske Mountains and Roztocze Upland, Poland. In: Corkum LD, Ciborowski JJH (Eds) Current Directions in Research on Ephemeroptera. Canadian Scholars Press, Toronto, 111-120.

Kazlauskas RS (1959) Materiali po faune podenok (Ephemeroptera) Litovskoy SSR s opisaniem novogo vida Eurylophella lithuanica Kazlauskas sp. n. i imago Neoephemera maxima (Joly) [Materials about the mayflies (Ephemeroptera) in Lithuanian SSR with description of new species Eurylophella lithuanica Kazlauskas and imago Neoephemera maxima (Joly)]. Vilniaus Valstybinio V. Kapsuko Vardo Universiteto Mokslo Darbai, Biologija, Geografija 1R Geologija 23 (6): 157-174 [in Russian].

Kovács T, Ambrus A (1999) Eurylophella karelica Tiensuu, 1935 in the Carpathian Basin (Ephemeroptera: Ephemerellidae). Folia Historico-Naturalia Musei Matraensis 23: 153-156.

Kovács T, Ambrus A, Juhász P, Olajos P, Szilágyi G (2008) Records of Ephemeroptera and Plecoptera from Lithuania, with notes on aquatic arthropods. Folia Historico-Naturalia Musei Matraensis 32: 119-134.

Kovács T, Olajos P, Szilágyi G (2011) Records of Ephemeroptera,
Odonata and Plecoptera from Lithuania, with notes on aquatic arthropods. Folia Historico-Naturalia Musei Matraensis 35: 21-32. Keffermüller M (1960) Badania nad fauna jętek (Ephemeroptera) Wielkopolski. Prace Komisji Biologicznej Pozna skie Towarzystwo Przyjaciól-Nauk, Wydzial-Matematyczno-Przyrodniczy 19 (8): 411-467.

Keffermüller M, Da Terra LSW (1978) The second European species of the subgenus Eurylophella Tiensuu (Ephemeroptera, Ephemerellidae, Ephemerella). Bulletin de l'Académie Polonaise des Sciences, Série des Sciences Biologiques (Cl.2) 26 (1): 29-33.

Martynov AV, Palatov DM, Godunko R (2015) The larvae of West Palaearctic Eurylophella Tiensuu, 1935 (Ephemeroptera: Ephemerellidae), with description of a new species from Georgia. Zootaxa 3904 (1): 123-143. https://doi.org/http://dx.doi.org/10.11646/zootaxa.3904.1.8

Ruginis T (2006) The checklist of mayflies (Insecta: Ephemeroptera) of Lithuania. Acta Zoologica Lituanica 16 (1): 67-76. https://doi.org/ 10.1080/13921657.2006.10512712

Sowa R (1961) Nowe stanovosko jetki Ephemerella karelica (Tiensuu) (=Eurylophella karelica Tiensuu). Acta Hydrobiologica 3 (1): 59-62.

Tiensuu L (1935) On the Ephemeroptera fauna of Laatokan Karjala (Karelia Ladogensis). Suomen Hyonteistieteellinen Aikakauskirja 1 (1): 3-23. 